This is a self-archived version of an original article. This version may differ from the original in pagination and typographic details.

Author(s): Granbom-Herranen, Liisa

Title: Tarton lähihistoria kiteytyy tarinaan inmismakkaratehtaasta

Year: 2014

Version: Published version

Copyright: (C) Kirjoittaja \& Suomen Kansantietouden Tutkijain Seura, 2014

Rights: In Copyright

Rights url: http://rightsstatements.org/page/lnc/1.0/?language=en

Please cite the original version:

Granbom-Herranen, L. (2014). Tarton lähihistoria kiteytyy tarinaan ihmismakkaratehtaasta.

Elore, 21(2). https://doi.org/10.30666/elore.79168 


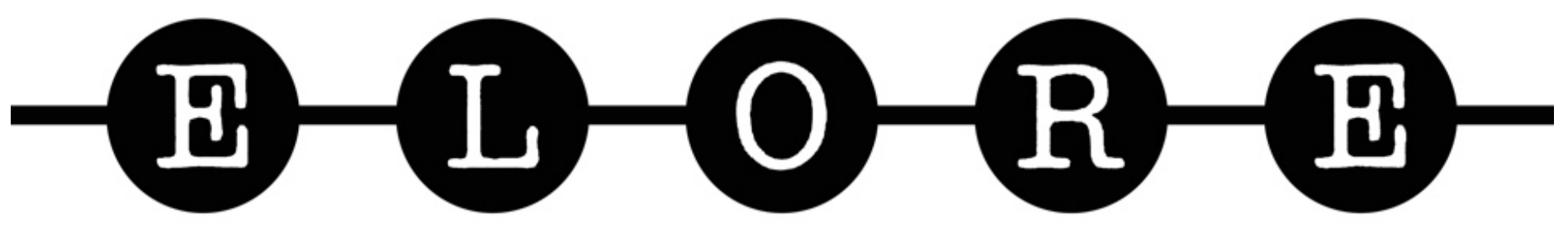

\section{TARTON LÄHIHISTORIA KITEYTYY TARINAAN}

\begin{tabular}{|c|}
\hline$f$ \\
\hline$y$ \\
\hline$G+$ \\
\hline
\end{tabular}
MISMAKKARATEHTAASTA

\section{Rumour in Tartu. On the Boundary of Two Worlds: Identity, Freedom, a in the Baltic 34. Amsterdam - New York: Rodopi. 180 sivua.}

\section{Liisa Granbom-Herranen}

Aloitin nykytarinoiden ja huhujen tutkimisen 1970-luvulla. Olin kyllästetty grillatuilla vauvoilla ja katoavilla liftar sosialistisessa neuvostotasavallassa tapahtui Tšernobylin ydinvoimalaonnettomuus. Onnettomuuden aikaan olin käynnissä käsivälitteisten puhelinvaihteiden toimintaa ja tiedon välitystä erämaa-alueilla rajoittava lakko. Tiedor kohtaamisten varassa. Muistan, että joku kertoi kuulleensa, että joku toinen henkilö oli kuullut radiosta edelliseı ydinvoimalan räjähdyksestä ja meitä lähestyvästä laskeutumasta. Tämä tekisi lumen juomavedeksi kelpaamattor vettä löytyisi metrisen jään alta. Ensimmäinen ajatukseni oli: mitä nyt? Heti perään tuli ymmärrys: tyypillinen huł tiedonsaannin kannalta eristetyssä tilassa. Kun sitten muutaman viikon jälkeen hiihdimme kylille, selvisi karu to

Tämä kokemus nousi elävästi mieleeni lukiessani Eda Kalmren teosta The Human Sausage Factory: $A$ Study of Pc uudenlainen avaus Neuvosto-Viron ja sosialismin jälkeisen Viron kaupunkitarinoiden eli urbaanien legendojen tı legend esiintyi ensimmäistä kertaa 1980-luvulla (Kalmre 1996). Virossa näitä tarinoita on jonkin verran tutkittu 2005), mutta Kalmre lähestyy genreä yhden tarinan kautta eikä tarkastele tarinaa ensisijaisesti genren näkökulm kaupunkitarinaa virolaisesta inmismakkaratehtaasta tapaustutkimuksena. Tarina sijoittuu yleensä joko Tarttoon kaikkialla Virossa varoitustarinana. Kirja on katsaus lähimenneisyyteen ja siinä paikallista tarinaa tarkastellaan s samankaltaisiin kertomuksiin. Kirjassa pohditaan sitä, kuinka ja miksi menneisyyden kuvauksilla ja aiemmilla us suuri merkitys sosialismin jälkeisessä Virossa. Teos on tiivis kuvaus, ja se perustuu Kalmren vuonna 2007 Tarto väitöskirjaan (Kalmre 2008).

\section{Tarina tutkimuksen pohjana}

Kaupunkitarinalla ihmismakkaratehtaasta on yhtäläisyyksiä varhaisempiin eurooppalaisiin ja amerikkalaisiin ihm 1800-luvuilta alkaen. Eda Kalmren teoksessa tarkastellaan nykytarinan elämänkiertoa Virossa ensimmäisinä vuo 
jälkeen. Teoksessa paneudutaan tarinaan ihmismakkaratehtaasta ja siihen liittyvien huhujen historialliseen kont esimerkkien kautta.

Vuonna 1947, toisen maailmansodan jälkeen, Tartossa levisi huhu makkaratehtaasta, jonka tuotteet valmistettii sijainneissa raunioissa oli nähty ihmisruumiin osia ja vaatteiden riekaleita. Näkijä oli torille maitoa myymään tull hänet oli johdattanut venäjää puhuva mies, kun tämä oli neuvonut naisen ystäviensä luo, jotka haluaisivat ostaa huutaen pakenemaan torille. Samana vuonna levisikin huhu useamman kymmenen ihmisen katoamisesta ja pääl 1940-luvulla huhun perusteella tehtiin poliisitutkinta, jota myös käsitellään kirjassa. KGB:n dokumentissa todet1 koko yhteiskuntajärjestelmää. Huhusta muodostui kollektiivinen, nopeasti levinnyt tarina, joka levitti kauhun iln ei tuonut rauhaa, vaan aloitti viidenkymmenen vuoden epävarmuuden kauden.

Vuonna 2001 julkaistiin Tartu Postimees -lehdessä kaksi artikkelia, joita varten toimittaja Alo Lõhmus haastatte \begin{tabular}{|c|l}
\hline$f$ & $\begin{array}{l}\text { tuntijana (Lõhmus } 2001 \text { a \& Lõhmus } 2001 \text { b). Kalmre kertoi kyseisen huhun sisältävän samoja elementtejä k } \\
\text { unkitarinat. Osa lehden lukijoista koki Kalmren näkemykset tarinasta vähätteleviksi ja loukkaaviksi, sillä he }\end{array}$ \\
\hline sia eikä mikä tahansa kaupunkitarina. Yhteydenotoissa kerrottiin tiedettävän henkilöitä, jotka olivat joutunє \\
eiksi. Kuten Leea Virtanen on todennut (1987), useimmiten kertojat olettavat heidän ja alkuperäisen kokijar
\end{tabular} mahdollisena historiallisena tapahtumana ja esimerkkinä erään aikakauden monimutkaisuudesta. Lehtiartikkeli I henkiin eli palautti sen aktiiviseksi osaksi kollektiivista muistia. Tarinasta ihmismakkaratehtaasta muodostui her ihmisille.

\section{Tarinan monet vaikutukset}

Teoksessa ei niinkään nosteta esille kysymystä siitä, oliko tällainen tehdas todella olemassa Tartossa, vaan asiac kertomusten kautta. Nykytarinaperinteeseen tutkimuskohde kytkeytyy esimerkiksi tutun ja tuntemattoman, oma tematiikan kautta.

Eda Kalmre on käyttänyt tutkimuksessaan aineistoja, joita ei ollut neuvostoajan poliittisessa ilmapiirissä mahdol haastatteluista, kirjeistä, sähköpostiviesteistä ja arkistolähteistä sekä KGB:n salaisiksi merkitsemistä kuulustelur dokumentit lisäävät tutkimuksen aineiston vaikuttavuutta. Dokumenttien englanninkieliset käännökset puolesta Ei-venäjänkielentaitoisena ja ei-neuvostovaltaa tuntevana olisin toivonut, että käytettyjen lyhenteiden (esimerkil olleet välittömästi tekstistä luettavissa sekä alkuperäisellä kielellä (venäjä) että kirjaimellisina käännöksinä.

Lisäksi kirjaan on saatu valokuvia tarinan kannalta keskeisistä paikoista Tartosta kyseisenä ajankohtana. Kirjan I esittävät sodassa tuhoutuneita osia Tartosta. Maailmansodan jälkeistä Tarttoa kuvaavat valokuvat ovat 2000-luv ja niitä on julkaistu useissa teoksissa, joiden aiheena on Tartto ennen ja nyt. Kuvat antavat lukijalle käsityksen $\mathrm{s}$ ennen toista maailmansotaa. Kuvat konkretisoivat tuhotun kaupungin tunnelmaa. Ei-tarttolainen lukija olisi hyö kirjaan. Samoin katujen vironkielisten nimien säilyttäminen olisi puoltanut paikkaansa. Tekstissä käytetyt englar vironkieliseen kadunnimien rakenteeseen tuntuvat vierailta.

Tietyissä olosuhteissa huhut ja tarinat saattavat nousta uudelleen ajankohtaisiksi ja siten niistä muodostuu osa muistia. Näin vaikuttaisi käyneen myös ihmismakkaratehtaasta kertovan tarinan kohdalla. Tarinalla on ollut sym sijoittuihan se juuri neuvostovallan alkuvuosiin sekä sodanjälkeisen ajan synkkään ja turvattomaan tunnelmaan. ajasta elävät edelleen osana kollektiivista muistia ja mainittu tarina aiheuttaa vieläkin useissa muistelijoissa tunr 
tunteet ovatkin kirjassa yhtenä tarkastelukohteena. Lähtökohtaisesti kyse on meistä ja heistä, sodassa vallatusta tapahtumia käsitelleestä folkloresta muodostui vaikuttava ja arvostelun mahdollistanut kanava.

Kirjassa on kontekstia taustoittavan johdantoluvun lisäksi kuusi lukua, joissa käsitellään ihmissyöntiä folkloristi! ilmiönä. Kalmre tarkastelee ihmismakkaratehdastarinan synnyn ajallista kontekstia suhteessa pahuuden ilmenty jakautuneen (tai jaetun) yhteiskuntajärjestelmän tuottaman rajoitetun tiedon merkitystä huhujen synnylle. Tämä elintarvikepulan vaikutusta kaupunkitarinoihin ja nykypäivän Virossa elävää kaupunkitarinaperinnettä. Viimeises tarinat ovat metaforisia sosiaalisia totuuksia. Tarinoissa kuvattu maailma oli niin voimakasvaikutteinen, että se I edelleen vaikuttaa ihmisten yksilöllisiin ja kollektiivisiin muistoihin, tunteisiin ja arvoihin. Kirjassa käsitellään tus kontrolloimatonta taloutta ja muistoja menetyksistä, mutta myös valintoja, uhmaa ja leppymättömyyttä.

\section{Lopuksi}

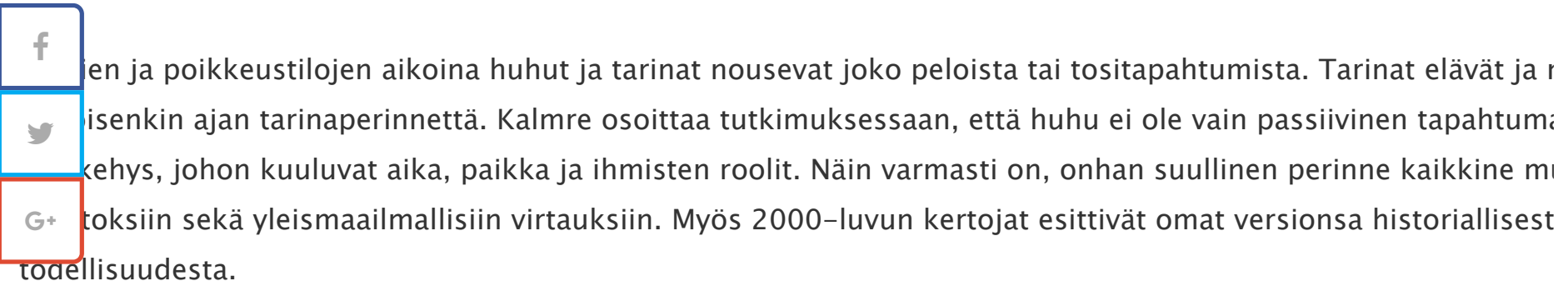

Kirja esittelee suomalaisten näkökulmasta toisenlaista maailmansodan jälkeistä aikaa. Toisessa maailmansodass (1939-1941) että saksalaisten (1941-1944) miehittämä, kunnes lopulta neuvostojoukot valtasivat sen 1944 ja vuoden 1991 uuteen itsenäisyyteen asti. Suomessakin on tarinoita tältä ajalta, mutta ne eivät ole olleet varsinais suhtauduttu vahvan emotionaalisesti. Meillä nykytarinat on yhdistetty 1950-luvulla alkaneeseen (länsimaiseen) I nopeutuneeseen kaupungistumiseen. Kalmre toteaa ihmismakkaratehdastarinan olleen tyypillinen sodanjälkeise ennakkoluulojen, arvojen ja stereotypioiden tuotos.

Eda Kalmren The Human Sausage Factory -teos on vaikuttava kokonaisuus. Kalmre on tehnyt perusteellista työt: analysoidessaan ilmiötä kokonaisuutena. Aineistosta on koostettu kokonaisuus, jossa näkyvät erilaisten aineisto ominaispiirteet sekä erityyppisten lähteiden mahdollistamat erilaiset lukemistavat. Kirja on saanut kiittävän vast 2014 International Society for Contemporary Legend Research (ISCLR) myönsi Eda Kalmrelle tästä teoksesta kan: kirjallisuuspalkinnon. Kyseessä oli ensimmäinen kerta, kun palkinto myönnettiin eurooppalaiselle, muulta kuin $\epsilon$ olevalle tutkijalle. Myös Akadeemiline Rahvaluule Selts [Akateemisen kansanrunoudentutkimuksen seura] ja Viro folkloristiikan tunnustuspalkinnon saajaksi Eda Kalmren.

\section{Kirjallisuus}

Kalmre, Eda 1996: Vorstivabrikust kassitoiduni. - Kõiva, Mare (toim.) Mängult-päriseltva. Tänapäeva folkloorist Eesti Keele Instituut. 136-155.

Kalmre, Eda 2008: Hirm ja võõrahviha sõjajärgses Tartus. Pärimuslooline uurimus kannibalistlikest kuulujuttudє Teaduskirjastus.

Kõiva, Mare 1998: Human Sausages in Estonia. - FOAFtale News 43: 1-2. 
Kõiva, Mare 2005: Fear, Honour and Shame. Horror fictions of the 1950s and 1960s. - Folklore. Electronic Jourr. < http://www.folklore.ee/folklore/vol29/fear.pdf > [7.11.2014.]

Lõhmus, Alo 2001 a: Inimvorstivabriku legend kui poliitiline õudusjutt. - Tartu Postimees 21.12.2001.

Lõhmus, Alo 2001 b: Tartu inimsõõjate saladus elab rahvajuttudes. Küüned pirukas ja sõrmus süldis - linnafolkl Postimees 13.11.2001.

Virtanen, Leea 1987: Varastettu isoäiti. Kaupungin kansantarinoita. Helsinki: Tammi.

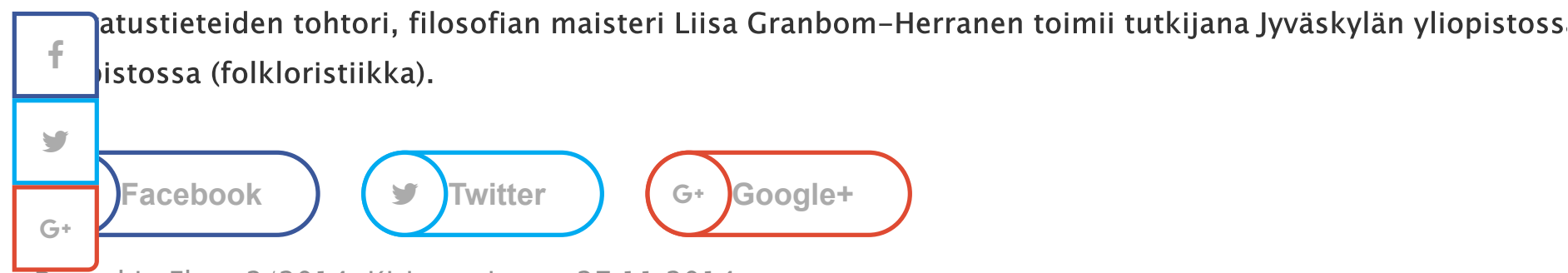

Posted in Elore 2/2014, Kirja-arviot on 27.11.2014.

Elore (ISSN 1456-3010) on tiettävästi

Suomen vanhin vapaan saatavuuden

verkkolehti. Elorea julkaisee Suomen

Kansantietouden Tutkijain Seura ry.

Logo: Jokke Saharinen

Taitto: Petja Kauppi, Tekstihuoltamo

Kielentarkastus (engl.): Tiina Mällo

Eloren sivuston kopioiminen on kielletty ilman päätoimittajan ja Kansantietouden Tutkijain Seuran lupaa.

Viitattaessa julkaisun teksteihin lähteenä mainitaan Elore ja viittaus tehdään 
artikkelin URL-osoitteeseen.

Tätä julkaisua saa tulostaa ja valokopioida

muuhun kuin yksityiseen käyttöön

edellyttäen, että teoksen käytöstä

vastaavalla organisaatiolla on voimassa

valokopiointisopimus tekijänoikeusjärjestö

Kopioston kanssa.

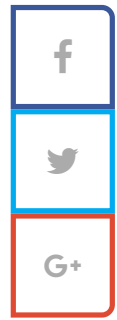

PROUDLY POWERED BY WORDPRESS · THEME: SUITS BY THEME WEAVER 